\title{
ENTOMOPHTHORAMYCOSIS BY Conidiobolus coronatus. REPORT OF A CASE SUCCESSFULLY TREATED WITH THE COMBINATION OF ITRACONAZOLE AND FLUCONAZOLE
}

\author{
Antonio Carlos Francesconi do VALLE(1), Bodo WANKE(2), Márcia dos Santos LAZÉRA(2), Paulo Cezar Fialho MONTEIRO(2) \& Maria de Lourdes VIEGAS(3)
}

\begin{abstract}
SUMMARY
Rhinoentomophthoramycosis caused by Conidiobolus coronatus in a 61-year old woman was unsuccessfully treated during 8 years with all the antifungals available in the Brazilian market, including potassium iodide for 1 month, sulfamethoxazole plus trimethoprim for 2 months, amphotericin B, total dose of $1130 \mathrm{mg}$, cetoconazole, $400 \mathrm{mg} /$ day for $6 \mathrm{months}$, fluconazole, $200 \mathrm{mg} / \mathrm{day}$, for at least 2 months and, itraconazole, $400 \mathrm{mg} /$ day for 2 months, followed by $200 \mathrm{mg} /$ day for 4 more months. Complete clinical and mycological cure was achieved using itraconazol $400 \mathrm{mg} /$ day in association with fluconazol $200 \mathrm{mg}$ /day during 24 months. After cure she was submitted to plastic surgery to repair her facial deformation. Today she remains clinically and mycologically cured after $59 / 60$ months (5 years!) without any specific antifungal. We thus suggest the use of the combination of itraconazole and fluconazole as an additional option for the treatment of this mycosis.
\end{abstract}

KEYWORDS: Entomophthoramycosis; Zygomycosis; Combination triazole treatment; Rhinoentomophthoramycosis.

\section{INTRODUCTION}

Entomophthoramycosis affects individuals with an apparently intact immunological status and occurs primarily in tropical areas. Two zygomycetes belonging to the order Entomophthorales are the etiologic agents of subcutaneous entomophthoramycosis: Basodiobolus ranarum $\left(=B\right.$. haptosporus) and Conidiobolus coronatus ${ }^{3,7}$. C. coronatus has already been isolated from soil samples, rotting plant matter, insects, and the gastrointestinal contents of lizards and frogs, especially in tropical and subtropical regions ${ }^{11}$.

Infection by $B$. ranarum manifests itself as a subcutaneous tumefaction located on the trunk, buttocks, or proximal portion of the limbs. Invasion of the abdominal and thoracic cavities by extension of the subcutaneous tumor mass has been reported. More recently there have been case reports with frankly visceral manifestations, with gastric and intestinal tumoral lesions, presenting as acute abdomen ${ }^{3,7}$.

Lesions by $C$. coronatus begin as infiltration of the nasal mucosa and submucosa, extending to the adjacent tissues of the paranasal sinuses, nasal dorsum, upper lip, and face, with no delimitation to their growth. The tumefaction, with a nodular or polipose infiltrative appearance, is covered by erythematous, hard skin, displaying continuity with the underlying tissues. The clinical manifestations result from the expansion of the tumor mass. Because of its initially central facial presentation affecting the nose first, the disease is also known as rhinoentomo- phthoramycosis. In the more advanced cases, the lesions can also affect the nasopharynx, oropharynx, palate, cervical region, and even the mediastinum $^{3,7}$. The first mycologically proven cases in humans were described independently and simultaneously in 1965 in Jamaica ${ }^{4}$ and Africa $^{12}$.

Cases of rhinoentomophthoramycosis have been described in Africa, Asia, and the Americas, ranging between the tropics of Cancer and Capricorn. The disease is essentially chronic, evolving over the course of years. No incubation period or cases of spontaneous involution are known. Diagnosis is made by clinical, histopathological, and mycological examination ${ }^{2}$.

According to the medical literature, treatment can be applied with satisfactory results using potassium iodide, amphotericin $\mathrm{B}$, and cetoconazole. However, the literature provides little information on longterm follow-up and/or relapses. We present a case of rhinoentomophthoramycosis caused by $C$. coronatus in which all the available antifungals, including itraconazole and fluconazole, had been used singly without success. However, the patient evolved to complete cure after long-term combination therapy with these two triazoles.

\section{CASE REPORT}

A 61 year-old white woman, domestic, living in the state of Maranhão, northeast Brazil, presented a history of a disease lasting 8

(1) Laboratory of Clinical Research, Research Center Evandro Chagas Hospital, Fundação Oswaldo Cruz (FIOCRUZ), Rio de Janeiro, RJ, Brazil.

(2) Laboratory of Medical Mycology, Research Center Evandro Chagas Hospital, Fundação Oswaldo Cruz (FIOCRUZ), Rio de Janeiro, RJ, Brazil.

(3) Hospital da Lagoa, Instituto Nacional de Seguridade Social (INSS), Rio de Janeiro, RJ, Brazil.

Correspondence to: Antonio Carlos Francesconi do Valle, Rua Machado de Assis, 24/903, Flamengo, 22220-060 Rio de Janeiro, RJ, Brasil. E-mail: afvalle@ cpqhec.fiocruz.br 


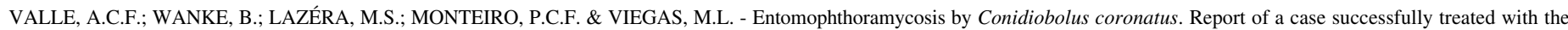
combination of itraconazole and fluconazole. Rev. Inst. Med. trop. S. Paulo, 43(4):233-236, 2001.

years (Fig. 1). During this period she was examined at several hospitals, and after obtaining the diagnosis of entomophthoramycosis based on clinical, mycological and histopathological findings, treated with the following drugs:

- potassium iodide for 1 month, with worsening of the lesions;

- sulfamethoxazole plus trimethoprim for 2 months, with no therapeutic response;

- amphotericin B, total dose of $1130 \mathrm{mg}$, with partial improvement; cetoconazole, $400 \mathrm{mg} /$ day for 6 months, with a favorable clinical response. Treatment was interrupted because the patient could not afford the medication. After a relapse, she resumed use of this medication, with no therapeutic response;

- fluconazole, $200 \mathrm{mg} /$ day, for at least 2 months, with no therapeutic response;

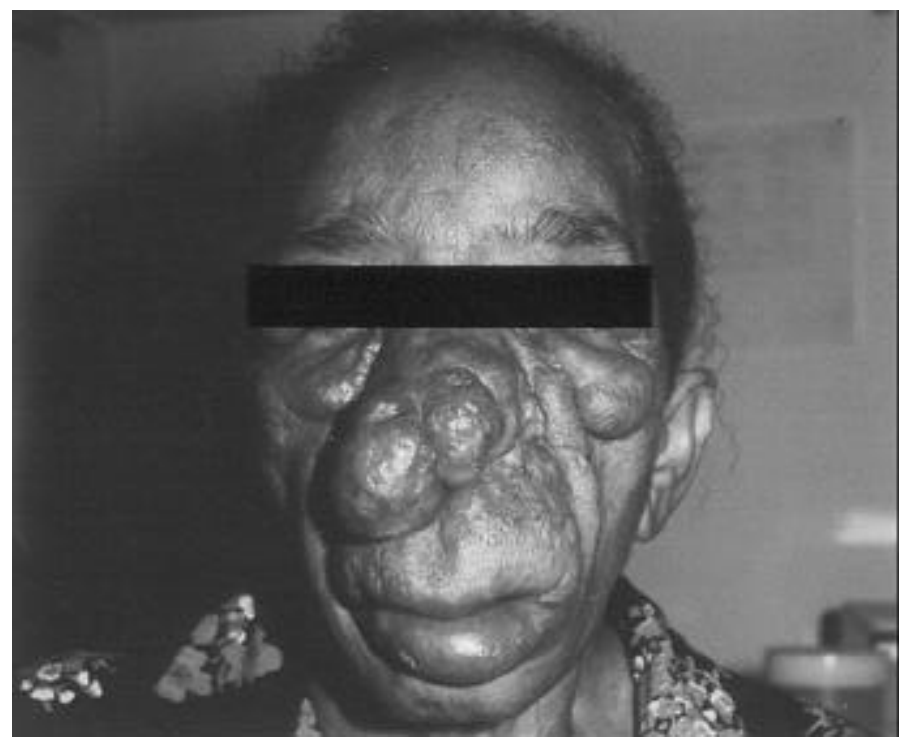

Fig. 1 - Aspect of the patient at admission.

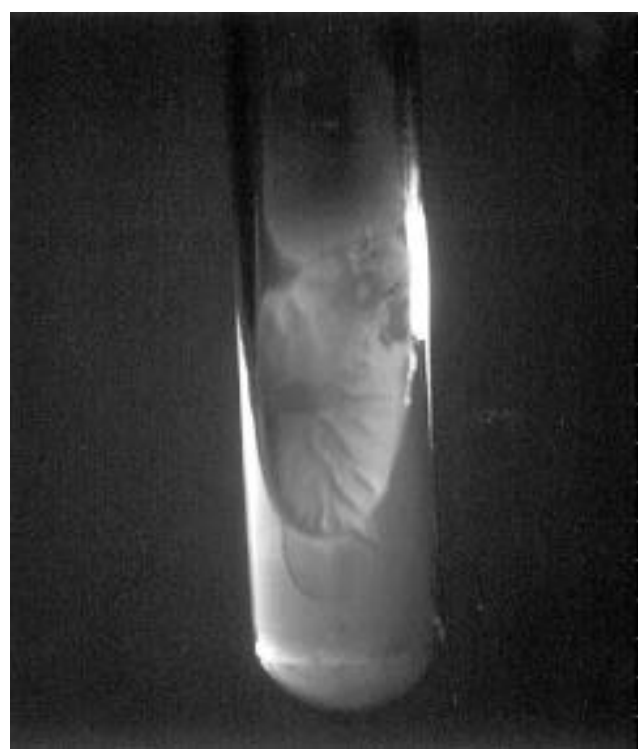

Fig. 2a - Culture of Conidiobolus coronatus. itraconazole, $400 \mathrm{mg} /$ day for 2 months, followed by $200 \mathrm{mg} /$ day for 4 more months, with no therapeutic response.

The patient was referred to the Evandro Chagas Hospital at the Oswaldo Cruz Foundation in Rio de Janeiro for specific treatment, where the diagnosis of rhinoentomophthoramycosis by $C$. coronatus was confirmed on clinical, histopathological, and mycological examination (Fig. 2a and 2b). At the beginning of April 28, 1993, due to the lack of other treatment options, we initiated combined oral fluconazole $200 \mathrm{mg} /$ day and itraconazole $400 \mathrm{mg} /$ day until April 1995. The patient evolved to clinical and mycological cure in 3 months (Fig. 3). Throughout treatment she was monitored every 2 months with clinical and mycological examination, complete blood count, and blood biochemical tests and presented no side effects or signs of toxicity. After the specific clinical treatment during 24 months, restorative surgery was performed to correct sequelae (Fig. 4). At the last clinical assessment, in March 2000, the patient had been off medication for 59 months and remained clinically cured.

\section{DISCUSSION}

Entomophthoramycosis occurs sporadically in tropical regions of Asia, Africa, and the Americas. The disease is caused by fungi living saprophytically in organic debris in the environment. So far only few cases of rhinoentomophthoramycosis caused by $C$. coronatus were reported. In Brazil, the first case was described by ANDRADE et al. in $1967^{1}$, only two years after the first reports on this mycosis in cases from Africa and Jamaica. Later on, cases were reported from the states of the North ${ }^{9,10}$ and more frequently from the Northeast of Brazil (states of Bahia, Piauí, Maranhão, and Sergipe $)^{1,2,6,8,14,17}$. In the present case the patient was a native of the state of Maranhão, reinforcing the Northeast as the main focus of this mycosis in Brazil.

Clinical and histopathological findings are quite suggestive, but definitive diagnosis is only possible by isolating and identifying the fungus in appropriate culture media. Clinically, the differential diagnosis 


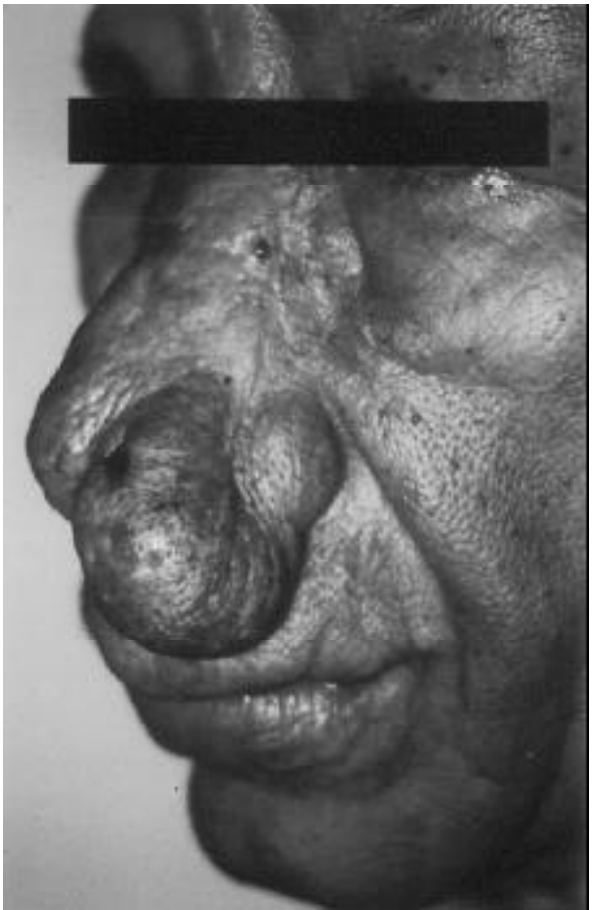

Fig. 3 - Aspect of patient's lesion 90 days after the use of the combination of itraconazole and fluconazole.

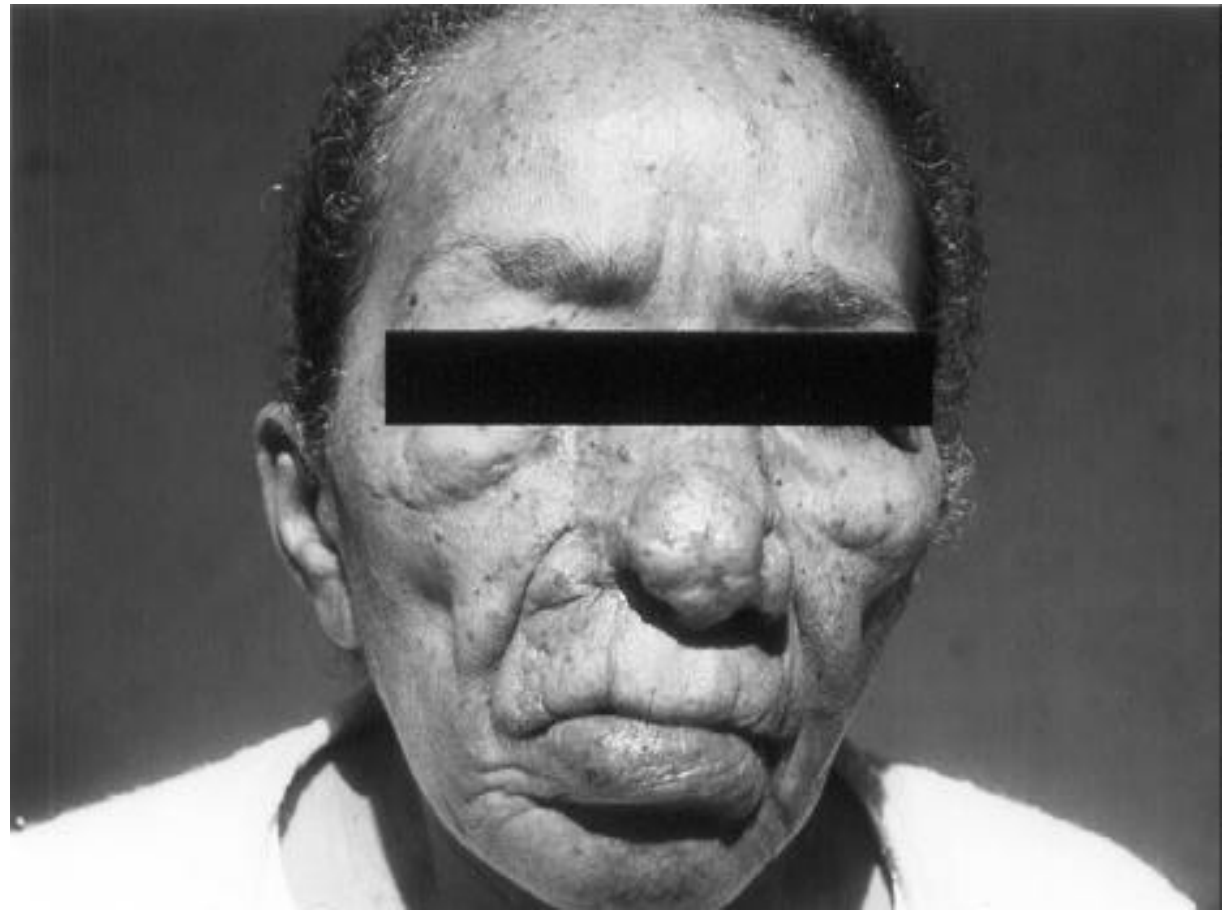

Fig. 4 - Aspect of the patient after 24 months of successful therapy and restorative surgery. should consider scleroma, rhynosporidiosis, and benign and malignant tumors of the nasal cavity ${ }^{8}$. Histopathological examination shows an inflammatory granulomatous reaction, with a predominantly mononuclear infiltrate consisting of lymphocytes, histiocytes, and some multinucleated giant cells, along with plasma cells and eosinophils. The central portion shows broad, thin-walled, irregular branching hyphae, frequently approaching right angles. These hyphae do not usually display septa and are surrounded by a peculiar eosinophilic mass (the SplendoreHoeppli phenomenon). The appearance is similar to that of subcutaneous entomophthoramycosis caused by $B$. ranarum. In our clinical case the diagnosis was based on clinical and histopathological examination confirmed by mycological identification of $C$. coronatus.

According to the literature, treatment of rhinoentomophthoramycosis has been performed successfully with potassium iodide ${ }^{3}$, combination sulfamethoxazole-trimethoprim ${ }^{5}$, amphotericin $\mathrm{B}^{3,5}$, and cetoconazole $\mathrm{e}^{8,17}$. All of these drugs were used unsuccessfully in the present case. Itraconazole and fluconazole, broad-spectrum triazolic derivative antifungals were used effectively against various other mycoses, had also been used singly to treat the patient, initially producing regression of the lesions, but with reactivation of the infection shortly afterwards.

All the antifungals available in Brazil in 1993 failed to cure the patient. Saperconazole, a new broad-spectrum imidazolic derivative, also was not available at that time because it has been removed from the market due to the development of tumors in laboratory animals. For lack of other options and based on reports of the successful use of multidrug therapy in various infectious diseases, we used a combination of itraconazole and fluconazole obtaining an excellent therapeutic response. In fact, the response was similar to that found by other authors in treating other mycoses with this combination therapy ${ }^{13,15,16}$. No side effects or drug-related toxicity were observed. We thus suggest the use of the combination of itraconazole and fluconazole as an additional option for the treatment of this mycosis. Possibly this may be also valid for other disseminated or opportunistic mycoses, especially in cases following treatment failure with the classic drug regimens.

Itraconazole and fluconazole are triazoles with similar mechanisms, acting especially on the fungal cell wall's cytochrome p450. However the underlying mechanism of a possible synergism between both drugs is so far unknown. We didn't find reports of antagonism between these two drugs.

Due to the lack of criteria for control of biological cure in this mycosis and the small number of cases reported in the literature, treatment is somewhat empirical, since the precise dosage and duration of treatment are unknown. In our case, as in others reported in the literature, there had been an initially favorable response to certain drugs, but their removal, perhaps too early, had led to in vivo resistance. Therefore, even with a clinical cure after 3 months, we maintained this combination drug therapy for over 19 months. There is a report of cure in this mycosis following surgical treatment, but in our case surgery was performed to correct sequelae, and the successive histopathological and mycological tests of the operatory specimens were negative.

\section{ACKNOWLEDGEMENTS}

The authors thank Dr. Alberto Thomaz Londero, Emeritus Professor of the Federal University of Santa Maria, RS-Brazil, for revising the text and helpful suggestions and, Professor Dr. Karel De Beule, Janssen Research Foundation, Beerse, Belgium, for comments and providing references. 


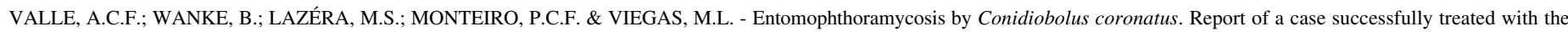
combination of itraconazole and fluconazole. Rev. Inst. Med. trop. S. Paulo, 43(4):233-236, 2001.

\section{RESUMO}

\section{Entomoftoramicose por Conidiobolus coronatus. Relato de um caso tratado com a associação de itraconazol com fluconazol}

É relatado um caso de rinoentomoftoramicose por Conidiobolus coronatus em mulher de 61 anos submetida a tratamento com todos os antifúngicos disponíveis no mercado brasileiro, durante 8 anos, sem sucesso, incluindo iodeto de potássio por 1 mês, sulfametoxazol associado ao trimetoprim por 2 meses, anfotericina B em dose total de $1130 \mathrm{mg}$, cetoconazol, $400 \mathrm{mg} / \mathrm{dia}$ por 6 meses, fluconazol, $200 \mathrm{mg} / \mathrm{dia}$, por pelo menos 2 meses, e itraconazol, $400 \mathrm{mg} / \mathrm{dia}$, por 2 meses, seguido de 200 $\mathrm{mg} /$ dia por mais 4 meses. A cura clínica e micológica completa foi obtida com a associação de itraconazol 400mg/dia com fluconazol $200 \mathrm{mg} / \mathrm{dia}$, durante 24 meses. Após a cura a paciente foi submetida a cirurgia restauradora. Atualmente a paciente encontra-se há 59 meses sem medicação específica permanecendo clínica e micologicamente curada.

\section{REFERENCES}

1. ANDRADE, Z.A.; PAULA, L.A.; SHERLOCK I.A. \& CHEEVER A.W. - Nasal granuloma caused by Entomophthora coronata. Amer. J. trop. Med. Hyg., 16: 31$33,1967$.

2. ANDRADE, Z.A. \& ANDRADE, S.G. - A entomoftorose nasal. Rev. Soc. bras. Med. trop., 6: 239-249, 1972.

3. BANDEIRA, V. \& LASCET, I.G. - Zigomicose. In: TALHARI, S. \& NEVES, R.G., ed. Dermatologia tropical. São Paulo, Medsi, 1995. p. 191-202.

4. BRAS, G.; GORDON, C.C.; EMMONS, C.W.; PRENDEGAST, K.M. \& SUGAR, M. A case of phycomycosis observed in Jamaica; infection with Entomophthora coronata. Amer. J. trop. Med. Hyg., 14: 141-145, 1965.

5. CAMPBEll, I. \& GOUVEIA, J. - Zigomicose. In: ZAitZ, C.; CAMPBELL, I.; MARQUES, A.S.; RUIZ, L.R.B. \& SOUZA, V.M., ed. Compêndio de micologia médica. Rio de Janeiro, Medsi, 1998. p. 205-218,

6. COSTA, E.F.; PORTUGAL, F.M.; PIVA, N. \& AGUIAR, K.V.M. - Zigomicose rinofacial: apresentação de um caso. An. bras. Derm., 74: 265-268, 1999.
7. ELLIS, D.H. - The zygomycetes. In: AJELLO, L. \& HAY, R.J. - Medical Mycology. 9. ed. London, Arnold; New York, Oxford University Press, 1998. p. 247-276. (COLLIER, L.; BALOWS, A. \& SUSSMAN, M. - Topley and Wilson's Microbiology and Microbial Infections v.4.)

8. FONSECA, A.P.M.; FONSECA, W.S.M.; LEAL, M.J.S. \& ARAÚJO, R.C. Rinoentomoftoromicose: relato de quatro casos. An. bras. Derm., 64: 261-265, 1989.

9. MORAES, M.A.P.; ARNAUD, M.C.V. \& ALMEIDA, M.M.R. - Zigomicose nasofacial no Estado do Pará: registro de dois casos. Rev. Soc. bras. Med. trop., 30: 329-331, 1997.

10. MORAES, M.A.; ALMEIDA, M.M.R.; VEIGA, R.C.C. \& SILVEIRA F.T. - Zigomicose nasofacial. Relato de um caso no estado do Pará, Brasil. Rev. Inst. Med. trop. S. Paulo, 36: 171-174, 1994.

11. PORTO, E.; MELO, N.T.; HEINS-VACCARI, E.M.; LACAZ, C.S. \& ASSIS, C.M. Isolamento de Conidiobolus coronatus (Costantin) Batko, 1964, de amostras de terra com e sem detritos vegetais. An. bras. Derm., 62: 303-307, 1987.

12. RENOIRTE, R.; VANDEPITTE, J.; GATTI, F. \& WERTH, R. - Phycomycose nasofaciale (rhinophycomycose) due a Entomophtora coronata. Bull. Soc. Path. exot., 58: 847$862,1965$.

13. SHICAMURA, I. - Evaluation of keratomycosis experienced in Ehime University for recent three years. In: JAPANESE ASSOCIATION FOR OCULAR INFECTION, 32., Japan, 1995. p. 50.

14. SILVA, J.F.; SILVA, W.M.; DANTAS, J.C.; ASSUNÇÃO, A.C.R. \& OLIVEIRA, M.M.S.T. - Rinoentomoftorose. Registro de um caso. Rev. Pat. trop., 4: 101-106, 1975 .

15. TAKAMATSU, K. \& OHTA, Y. - One case with cryptogenic severe sub-acute meningitis successfully treated with cerebral ventricle-peritoneal shunt combined with antifungal treatment. In: MEETING OF THE JAPANESE SOCIETY OF NEUROLOGICAL THERAPEUTICS, 13., Japan, 1995. p. 56.

16. TELLES, F.Q.; FILLUS, J.N.; SAAD, L.M. et al. - Successful treatment of cerebral phaeohyphomycosis with azole combined therapy. In: SYMPOSIUM ON TOPICS IN MYCOLOGY: FUNGAL DIMORPHISM, 4., Cambridge, 1992. p. 284.

17. TOWERSEY, L.; WANKE, B.; ESTRELLA, R.R. et al. - Conidiobolus coronatus infection treated with ketoconazole. Arch. Derm., 124: 1392-1396, 1988.

Received: 27 October 2000

Accepted: 15 March 2001 